\title{
Fish assemblages in a small temperate estuary on the Argentinian coast: spatial variation, environmental influence and relevance as nursery area
}

\author{
Agustín Solari $^{1,2 *}$, Andrés J. Jaureguizar ${ }^{3,4}$, Andrés C. Milessi ${ }^{3,4}$, Mirta L. García ${ }^{2,5}$ \\ ${ }^{1}$ Instituto de Biología Subtropical - Iguazú (CONICET/UNAM) \\ (Bertoni 85, 3370, Puerto Iguazú, Misiones, Argentina) \\ ${ }^{2}$ Consejo Nacional de Investigaciones Científicas y Técnicas, Argentina \\ ${ }^{3}$ Instituto Nacional de Investigación y Desarrollo Pesquero \\ (Paseo Victoria Ocampo No. 1, 7602, Mar del Plata, Argentina) \\ ${ }^{4}$ Comisión de Investigaciones Científicas de la Provincia de Buenos Aires, Argentina \\ ${ }^{5}$ Facultad de Ciencias Naturales y Museo, Universidad Nacional de La Plata \\ (Paseo del Bosque s/n, 1900, La Plata, Argentina) \\ *Corresponding author: kevianus@gmail.com
}

\section{Abstract}

The effects of different environmental variables on the fish community structure were evaluated in a small temperate estuary. The biological and environmental data were collected bimonthly between 2007 and 2009 along the main estuarine axis. Multivariate analyses were applied (CLUSTER, SIMPER, CCA) to determine the spatial structure of fish community and to estimate the environmental influence on it. A total of 48 species of "teleost" fishes were observed, with the families Characidae and Sciaenidae presenting the largest number of species, $90 \%$ of the catches being juveniles. The fish community was overwhelmingly dominated by one species (Micropogonias furnieri, $88.9 \%$ ), and only four species contributed more than $1 \%$ of total catch (Odontesthes argentinensis 5.4\%, Brevoortia aurea 1.1\%, Paralonchurus brasiliensis $1.1 \%$, and Mugil platanus 1.0\%). Estuarine and freshwater stragglers dominated in number of species, followed by freshwater migrants and marine migrants. Three areas with different fish assemblages, with distinctive species and functional guilds, were defined along the main axis. The occurrence and spatial spread of these areas were linked to spatial variation in salinity, which was consistently influenced by discharge from the Río de la Plata and local precipitation. The results highlight the importance of shallow environments as nursery areas and permit emphasis on their susceptibility to environmental changes.

Descriptors: Ajó River, Río de la Plata, Fish assemblage, Juvenile fish, Salinity gradient.

\section{RESUMO}

Foram avaliados os efeitos das diferentes variáveis ambientais na estrutura da comunidade de peixes em um pequeno estuário temperado. Dados biológicos e ambientais foram obtidos bimestralmente entre 2007 e 2009, ao longo do eixo principal do estuário. Análises multivariadas foram aplicadas (CLUSTER, SIMPER, CCA) para determinar a estrutura espacial da comunidade de peixes e para estimar a influência ambiental sobre ela. Um total de 48 espécies de "teleósteos" foi observado, com as famílias Characidae e Sciaenidae apresentando o maior número de espécies e sendo $90 \%$ das capturas formada por juvenis. A comunidade de peixes foi altamente dominada por uma só espécie (Micropogonias furnieri, 88,9\%) e quatro espécies contribuiram com pouco mais de $1 \%$ cada para o total das capturas (Odontesthes argentinensis 5,4\%, Brevoortia aurea 1,1\%, Paralonchurus brasiliensis $1,1 \%$ e Mugil platanus 1,0\%). Retardatários estuarinos e de água doce dominaram em número de espécies, seguidos por migrantes de água doce e marinhos. Ao longo do eixo principal foram definidas três áreas distintas, cada uma apresentando assembleias de peixes com espécies e guildas funcionais distintas. A ocorrência e abrangência espacial dessas áreas estiveram ligadas à variação espacial na salinidade, que consistentemente foi influenciada pela descarga do Rio da Prata e pela precipitação local. Os resultados destacam a importância dos ambientes rasos como áreas de berçário e permitem enfatizar sua susceptibilidade às mudanças ambientais.

Descritores: Rio Ajó, Rio de la Plata, Assembleia de peixes, Peixes juvenis, Gradiente de salinidade. 


\section{INTRODUCTION}

The spatial organization of fish assemblages presents a complex temporal pattern in estuarine systems (BLABER et al., 1989). These estuaries' various biotic and abiotic features permits the coexistence of fish of different origins (freshwater and marine), moreover, they can cooccur throughout their life cycle or at a particular stage, especially in juvenile stages (POTTER et al., 1990; BECK et al., 2001; ELLIOTT et al., 2007). This leads to the diversity of the species that compose the fish assemblages, to be determined by the tolerance of these species to changes in biotic and abiotic variables (WHITFIELD, 1999). The majority of species that inhabit these systems tolerate salinity fluctuations, but their level of adaptability and physiological tolerance finally determine the pattern of zonation evidenced in the fish assemblages of estuarine systems (WHITFIELD, 1999; JAUREGUIZAR et al., 2003a).

With the aim of getting a representative and holistic view of the fish community structure in a particular environment, the use of traditional taxonomy with tests of functional guilds is an excellent option to obtain a representative and holistic view of the fish community structure in a particular environment (FRANCO et al., 2008). Knowledge of the functional traits of fish assemblages is a great way to understand the ecological function of those environments (BLABER, 2008). The designation of functional groups is an important tool to simplify the structure and dynamics of ecosystems, which facilitates the understanding of complex factors (BLONDEL, 2003). Functional aspects give an important overview regarding ecosystem health; these are tools that may help in decision-making processes related to the management of estuarine environments (MATHIESON et al., 2000) and serve to emphasize the importance of these systems as migration routes, and food and shelter areas for various species (FRANCO et al., 2008). It is noteworthy that several estuarine systems are important refuge areas for fish species of great economic and/or environmental value (ELLIOTT; HEMINGWAY, 2002). This consideration, coupled with the development of other human activities and climate variations/change, has created the need to establish, using available information (biological and/or environmental), reference conditions or states of estuarine systems, allowing the assessment of possible responses to those stressors (LOBRY et al., 2003). The effect of these factors will be reflected in changes in the availability of resources, and therefore, in the dominance or presence of some functional groups (ELLIOTT et al., 2007). The species' response to these changes can be considered as a measure of the resilience of the system in the face of the factors responsible, making them a valuable tool for the development of conservation measures for these systems.

The Ajó river (RA) has an average width of $120 \mathrm{~m}$ and a length of approximately $25 \mathrm{~km}$, and discharges its water into the southern region of Samborombón Bay (36²0'12"' S, 56 54'17' W), within the Río de la Plata (RdlP) estuary (Fig. 1). The RA is part of an International Ramsar site (№ 885) and Campos del Tuyú National Park. This environment has a strong salinity gradient, the surface water temperature ranges from 9 to $25.8^{\circ} \mathrm{C}$ (MARTIN; BASTIDA, 2006), mainly influenced by the seasonal dynamic of RdlP's brackish waters and by the pluvial discharge, the annual average precipitation being 1,078 $\mathrm{mm}$ with the heaviest rainfall occurring in summer. The substratum is mainly dominated by silt and clay sediments (MARTIN; BASTIDA, 2006), and this system possesses a salt marsh physiognomy with a complex network of tidal channels, areas that act as organic matter exchangers between the terrestrial and marine environments through the action of the tides. The estuary sector of the RdlP has a semidiurnal regimen with diurnal inequality, maximum variation being close to $1 \mathrm{~m}$ (SIMIONATO et al., 2004), with spring tides of between 0.37 and $1.46 \mathrm{~m}$ and ebb tides between 0.58 and $1.25 \mathrm{~m}$ (MARTIN; BASTIDA, 2006). Its brackish water dynamic is mainly forced by the freshwater discharge of RdlP (on a relatively long time scale) and the predominant winds (on a relatively short time scale) (GUERRERO et al., 1997; SIMIONATO et al., 2005). The RA fish composition (45 species) is mainly characterized by Characiformes and Perciformes (10 species), followed by Siluriformes (6 species), Clupeiformes (5 species), Atheriniformes and Pleuronectiformes (3 species) (SOLARI et al., 2009). The combination of freshwater, euryhaline and marine species clearly indicates the great variety of habitats available along the RA environmental gradient, and the relative influence of adjacent waters (freshwater and marine water), according to the degree of intrusion, on the seasonal fish composition.

Various studies have shown that the RdlP region is undergoing environmental change. A significant increment in frequency and height of waves towards the Samborombón Bay (CODIGNOTTO et al., 2012), a regime shift in sea surface temperature, wind stress, and surface currents (AUAD; MARTOS, 2012), an increasing speed 


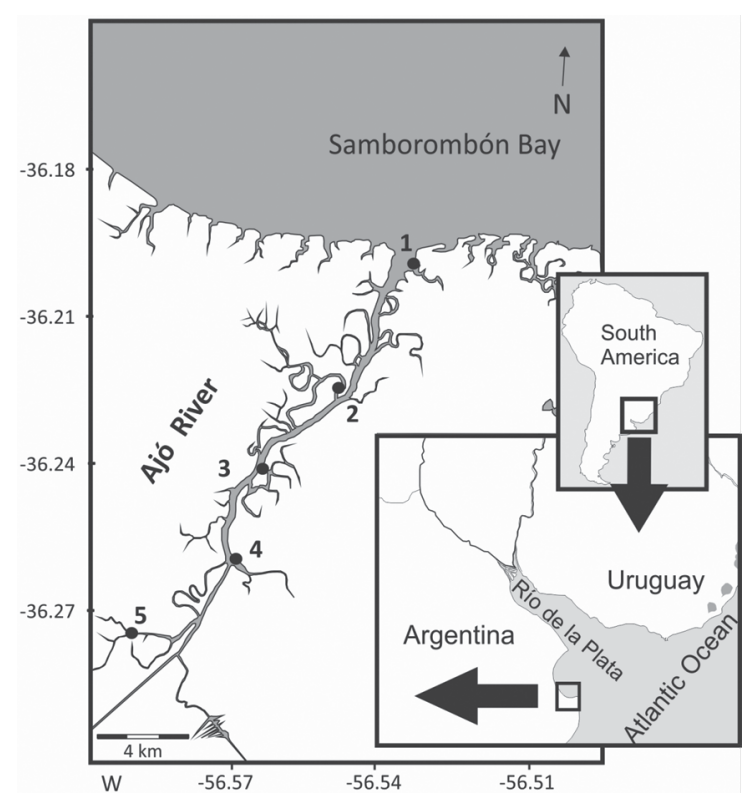

Figure 1. Study area and sampling stations (1 to 5, black circles).

and monthly frequency of southern winds (ORTEGA et al., 2012), and an increase in the regional rainfall and river runoff were documented in the RdlP drainage basin during the 20th century (PASQUINI; DEPETRIS, 2007). This evidences that the RdlP region is under the influence of climatic variability, which coupled with a major change in resource exploitation and management (JAUREGUIZAR; MILESSI, 2008) and anthropogenic influence (discharge of domestic effluents, port activity, dredging, introduction of exotic species, and growing urbanization (CAROL et al., 2007; GARCÍA et al., 2010)), can amplify the magnitude of change in the use of the different estuarine habitats of the RdlP by fish. It is then vital to explore the environmental influence along the different estuarine habitats of the RdlP, not only as a means of understanding the relationship between species and the environment, but also to contribute to future ecosystem-wide management of the RdlP.

\section{MATERIAL AND METHODS}

\section{Data Collection}

Fish were collected bimonthly between winter 2007 and spring 2009 (during 13 surveys), at five stations at a distance of approximately $5.5 \mathrm{~km}$ from each other, arranged to cover the entire salinity gradient. Sampling was done with a fixed net modified by COLAUTTI (1998), with two 15-m long and 1-m high lateral wings having a $5-\mathrm{mm}$ mesh size and $3-\mathrm{m}$ cod end. The net remained for $24 \mathrm{~h}$ in each sampling location. All fish were identified in accordance with the available bibliography (RINGUELET et al., 1967; MENNI et al., 1984; AZPELICUETA; ALMIRÓN, 1991; CASCIOTTA et al., 2005; MIQUELARENA; MENNI, 2005; MIQUELARENA; LÓPEZ, 2006), and counted to determine the density and to analyse fish community composition. The densities were standardized to number of individuals caught per hour. All fish individuals were measured to the nearest $0.5 \mathrm{~cm}$ total length. Water salinity and temperature (YSI Model 33SCT meter), oxygen (Hanna HI 9142) and pH (Universalindikator MERK), and total suspended material (mg/l), were measured on every sampling occasion at each station.

The RdlP monthly runoff between years 1909 and 2009 was provided by the Subsecretaria de Recursos Hidricos de la Nación. Using this information the monthly anomaly was calculated for the time of study. Rainfall records were provided by the Municipalidad de General Lavalle. Rainfall data were used for the cumulative rainfall of the 10 days and 30 days before each sampling date.

\section{DATA ANALYSIS}

To analyse the spatial variations in composition and structure fish community and their relationship with specific physico-chemical variables, species abundance (ind $/ \mathrm{h}$ ) was used and the fish species were allocated to estuarine categories in accordance with WHITFIELD (1999): estuarine residents, species that possess the ability to complete their life cycle within the estuary; marine migrants, species that make extensive use of estuaries during juvenile and/or adult life stages; marine stragglers, species that were recorded in small numbers, usually in the lower reaches; freshwater migrants, species that are present in a wide range of estuaries throughout the year; freshwater stragglers, species that enter certain estuaries for brief periods when conditions are favourable; catadromus, species that spawn at sea but use freshwater catchment areas for their juvenile and subadult life stages; and anadromus, species that spend their phase of greatest growth at sea and, prior to reaching maturity, migrate into rivers where spawning subsequently occurs. Only species that occurred in more than $2 \%$ of catches in all the seasons were included in the Bray-Curtis similarity matrix. Species abundance data were $\log 10$ $(x+1)$ transformed to reduce the dominance effect of some species. 
With the aim of obtaining a visual representation of the similarities between sampling sites and determine areas of species associations (average similarity $\geq 60 \%$ ), the matrices were subject to multivariate hierarchical cluster analysis (CLUSTER). Analysis of similarity of percentages (SIMPER) was applied to identify the species responsible for the similitude within the area and also those species that contributed to differences between areas. Species that contributed with $90 \%$ of the average similarity of the area were identified as common, while those which contributed more than $1 \%$ of the dissimilarity between areas were classified as discriminant. These analyses were performed using the Plymouth Routines in Multivariate Ecological Research package (PRIMER 5) (CLARKE; WARWICK, 2001).

The influence of the environmental variables [salinity $(\mathrm{S})$, temperature $(\mathrm{T})$, oxygen $(\mathrm{O}), \mathrm{pH}$, total suspended material (MS), precipitations (pp10 and pp30) and RdlP freshwater discharge (RdlP)] on the fish communities' spatial and temporal composition was analyzed using Canonical Correspondence Analysis (CCA). All environmental variables were used in a first analysis and the significance was tested with a forward selection procedure. Afterwards, a second analysis was performed using only the significant environmental variables. The CCA method assumes that species have a unimodal distribution along the environmental gradients (JONGMAN et al., 1995). The statistical significance of the ordination method was obtained by the Monte-Carlo permutations test (199 permutations). The species/samples scores and intraset correlations obtained by CCA were plotted using a biplot with the environmental variables represented by vectors. The lengths of the vectors on the biplot indicate the magnitude of their relative importance in the ordination, and the position and direction of the vectors indicate how they are correlated with each other and with each axis. The relative position of species/samples along the vectors reflects how species/samples are associated with each factor relative to the other species/samples. The abundance data were transformed by $\log 10(x+1)$ to minimize the influence of extreme values and zeros. These analyses were performed using the CANOCO version 4.02.

\section{RESULTS}

\section{ENVIRONMENTAL DATA}

Salinity fluctuated significantly along the RA, the maximal average values occurred at sites near the mouth
(17.1 \pm 4.1 , average and standard deviation respectively) and the minimum averages upstream $(10 \pm 7.2)$ (Table 1). Temperature had a strong seasonal variation; however, no spatial variations were evident in any of the surveys (Table 1). Dissolved oxygen, $\mathrm{pH}$ and total suspended material were higher in the mouth (Table 1) than upstream. Rainfall showed no annual pattern, presenting a peak in the spring of 2007 and another in late summer of 2009, the latter preceded by a dry period that lasted from late spring 2008 to early summer 2009 (Fig. 2). The freshwater discharge of RdlP was higher during the spring months and lower during the autumn, reaching the lowest values from January to July 2009 (Fig. 2).

\section{TAXONOMIC DISTRIBUTION AND FUNCTIONAL GROUPS}

A total of 48 species of teleost fishes, distributed in 13 orders and 27 families, were recorded for the RA (Table 2). The families with higher species richness were Characidae and Sciaenidae with 7 and 6 species respectively; only one family (Clupeidae) has three species, while the remainder was represented by two or one species. The highest average abundance was found at sampling site 3 (13 species $-50 \%$ of abundance ind $/ h$ ), while the sampling site with extreme salinity values (low or high) showed the lowest values of species richness and abundance (Table 2). A total of 15 species were ubiquitous along the RA, while others were exclusively found at the middle ( 7 species), external ( 3 species) or internal ( 3 species) sampling sites, whereas the intermediate sites (sites 2 and 4) did not exhibit exclusive species. Freshwater stragglers species dominated in number of species $(\mathrm{n}=16)$, followed by estuarine residents $(\mathrm{n}=13)$, and marine migrants $(\mathrm{n}=7)$. The other functional groups accounted for 6 (freshwater migrants), 4 (marine stragglers) or 1 species by group (catadromus and anadromus). However in terms of abundance the dominant species was an estuarine resident, Micropogonias furnieri (88.9\%), while only three more estuarine residents (Odontesthes argentinensis 5.41\%, Brevoortia aurea $1.15 \%$ and Paralonchurus brasiliensis $1.13 \%$ ) and a catadromus (Mugil platanus 1.03\%), were represented by more than $1 \%$. The remaining 43 species, more than $70 \%$, contributed less than $1 \%$ of the total catch. M. furnieri abundance reached a peak in the middle area and its minimum values occurred at both extreme sampling sites (Table 2). All the individuals of $M$. furnieri were juveniles belonging to the $0+(<120 \mathrm{~mm})$ and $1+$ $(130-250 \mathrm{~mm})$ age classes, $99 \%$ of individuals being of less than $155 \mathrm{~mm}$ total length (Fig. 3). The rest of the most 
Table 1. Average \pm standard deviation values, of physico-chemical variables by sampling site in the Ajó river. S: salinity; T: temperature; O: oxygen; MS: Total suspended material.

\begin{tabular}{lccccc}
\hline Sites & $\mathrm{S}$ (ups) & $\mathrm{T}\left({ }^{\circ} \mathrm{C}\right)$ & $\mathrm{O}(\mathrm{mg} / \mathrm{l})$ & $\mathrm{pH}$ & $\mathrm{MS}(\mathrm{mg} / \mathrm{l})$ \\
\hline 1 & $17.1 \pm 4.1$ & $17.0 \pm 5.3$ & $8.5 \pm 1.0$ & $6.5 \pm 0.8$ & $814.6 \pm 646.5$ \\
2 & $14.8 \pm 6.2$ & $16.8 \pm 5.2$ & $7.6 \pm 1.5$ & $6.2 \pm 0.8$ & $266.5 \pm 93.0$ \\
3 & $13.3 \pm 6.1$ & $17.2 \pm 5.3$ & $7.5 \pm 1.5$ & $6.2 \pm 0.7$ & $226.5 \pm 126.9$ \\
4 & $11.3 \pm 6.5$ & $17.1 \pm 5.5$ & $7.4 \pm 1.8$ & $6.1 \pm 0.7$ & $262.8 \pm 146.3$ \\
5 & $10.0 \pm 7.2$ & $17.4 \pm 5.1$ & $7.1 \pm 1.9$ & $6.1 \pm 0.6$ & $173.3 \pm 75.3$ \\
\hline
\end{tabular}

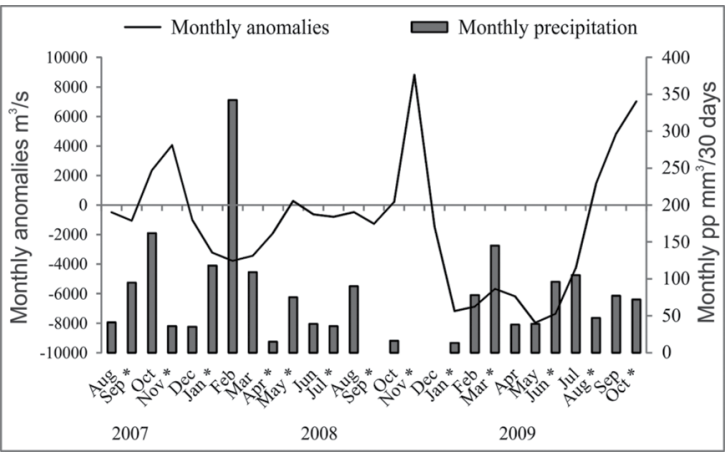

Figure 2. Río de la Plata anomaly discharges (based on the monthly average of $19682 \mathrm{~m}^{3} / \mathrm{s}$ calculated from 1909 to 2009); and monthly precipitation registered in the Municipality of General Lavalle. * Months in which the surveys were carried out.

abundant species $(>1 \%)$ were also represented almost entirely by juvenile individuals (Fig. 3), and occurred throughout the entire system, except $P$. brasiliensis that appears mostly in the lower parts of the estuary without reaching the system's upper reach (Table 2).

\section{SPATIAL VARIATION AND ENVIRONMENTAL INFLUENCES}

In spite of various spatial patterns obtained by cluster analysis of sites during the sampling time, this method succeeded in identifying a consistent pattern of three main fish assemblage areas (Table 3). They corresponded with continuous geographical areas throughout the system (external, middle and internal), which were determined by the species composition rather than by changes in their abundances. The external area had an average similarity between $60 \%$ and $76 \%$ (SIMPER), with Menticirrhus americanus (marine migrant), $M$. furnieri, $O$. argentinensis, $B$. aurea, Pogonias cromis, $P$. brasiliensis, Macrodon ancylodon, Syngnathus folletti (estuarine residents), and M. platanus (catadromus) as common species. The discriminant species of this area were mainly marine migrants and estuarine residents, $M$. americanus being the most characteristic species (Table 4). The middle area had average similarities between $57 \%$ and $83 \%$, and common species were Cynoscion guatucupa (marine migrant), M. furnieri, $O$. argentinensis, $B$. aurea, P. cromis, M. ancylodon, Platanichthys platana (estuarine residents), M. platanus (catadromus), and freshwater species such as Rhamdia quelen, Cyphocharax voga, Corydoras paleatus, Cheirodon interruptus, Oligosarcus jenynsii and Cyprinus carpio. This area was mainly discriminated by estuarine residents (Table 4). Finally, the inner area showed similarity between $60 \%$ and $74 \%$; the common species were C.voga, C. paleatus, C. interruptus (freshwater stragglers), M. furnieri, O. argentinensis, B. aurea, P. cromis, M. ancylodon, P. platana (estuarine residents), and Lycengraulis grossidens (anadromus); and it was mainly discriminated by freshwater and estuarine species (Table 4).

The first two axes of the CCA ordination diagram explained $14.4 \%$ of the variance of species variation and $75.4 \%$ of the species-environment relationship (Table 5). The overall test of significance for the first canonical axis, as well as for the sum of all axes was significant (Monte Carlo Test: $\mathrm{F}=5.8 ; p=0.002$, and $\mathrm{F}=3.05 ; p=0.002$ respectively) (Table 5). The eigenvalues for each axis showed that the gradient represented by the first canonical axis, which explained $46.6 \%$ of the species-environment relationship and $8.9 \%$ of the variation among species (Table 5), was the most important for the spatial distribution of species composition. The correlation of axis 1 with the variables indicated that salinity has the greatest influence in determining this pattern (Table 5). Meanwhile, axis 2 explained $28.8 \%$ of the species-environment relationship (Table 5); it was mainly associated with temperature, and secondarily with local precipitation and RdlP discharge (Table 5). It represented the most important seasonal change in the species composition during the study period (Fig. 4). The largest discontinuity along the first axis produced three main groups of species associated with high, intermediate and low salinities (Fig. 4). The group of species associated with high salinities was composed of marine species (Urophycis brasiliensis, C. guatugupa, 
Table 2. Fish species collected in the Ajó river, and frequency percent of abundance (ind/h) occurrence at the study sites. EUFG: estuarine use functional groups; er: estuarine resident; $f s$ : freshwater stragglers; $f m$ : freshwater migrants; $m s$ : marine stragglers; $m m$ : marine migrants; $c$ : catadromus; $a$ : anadromus.

\begin{tabular}{|c|c|c|c|c|c|c|c|}
\hline \multirow[t]{2}{*}{ Order/Family } & \multirow[t]{2}{*}{ Species } & \multicolumn{5}{|c|}{$\%$ of species abundance by site } & \multirow[t]{2}{*}{ EUFG } \\
\hline & & 1 & 2 & 3 & 4 & 5 & \\
\hline \multicolumn{8}{|c|}{ Anguilliformes } \\
\hline Congridae & Conger orbignyanus (Valenciennes, 1847) & - & - & 100 & - & - & $m s$ \\
\hline \multicolumn{8}{|l|}{ Clupeiformes } \\
\hline \multirow[t]{2}{*}{ Engraulidae } & Anchoa marinii Hildebrand, 1943 & - & $<$ & 79.9 & $<$ & 19.2 & er \\
\hline & Lycengraulis grossidens (Agassiz, 1828) & 7.9 & 23.7 & 52.6 & 7.9 & 7.9 & $a$ \\
\hline \multirow[t]{3}{*}{ Clupeidae } & Brevoortia aurea (Spix \& Agassiz, 1829) & 1.7 & 2 & 40.6 & 25.5 & 30.3 & er \\
\hline & Platanichthys platana (Regan, 1917) & $<$ & 6.9 & 22 & 35.2 & 35.6 & er \\
\hline & Ramnogaster arcuata (Jenyns, 1842) & - & 50 & - & 50 & - & er \\
\hline \multicolumn{8}{|l|}{ Cypriniformes } \\
\hline Cyprinidae & Cyprinus carpio (Linnaeus, 1758) & - & 4 & 86.4 & 2.4 & 7.2 & $f m$ \\
\hline \multicolumn{8}{|l|}{ Characiformes } \\
\hline \multirow[t]{2}{*}{ Curimatidae } & Cyphocharax spilotus (Vari, 1987) & - & - & 45.3 & - & 54.7 & $f_{s}$ \\
\hline & C. voga (Hensel, 1870) & $<$ & 9 & 10.1 & 26.2 & 54.2 & $f_{S}$ \\
\hline \multirow[t]{7}{*}{ Characidae } & Astyanax eigenmanniorum (Cope, 1894) & 14 & 7 & 51.2 & 7 & 20.9 & $f_{S}$ \\
\hline & A. pampa Casciotta et al. 2005 & - & - & 50 & 50 & - & $f_{S}$ \\
\hline & Bryconamericus iheringii (Boulenger, 1897) & - & - & 100 & - & - & $f_{S}$ \\
\hline & Cheirodon interruptus (Jenyns, 1842) & - & 3.2 & 62.6 & 18.9 & 15.3 & $f_{s}$ \\
\hline & Hyphessobrycon anisitsi (Eigenmann, 1907) & - & - & - & - & 100 & $f_{S}$ \\
\hline & H. togoi (Miquelarena \& López, 2006) & - & - & - & - & 100 & $f_{s}$ \\
\hline & Oligosarcus jenynsii (Günther, 1864) & - & 12 & 22 & 41.6 & 24.4 & $f_{s}$ \\
\hline Cynodontidae & Raphiodon vulpinus Agassiz, 1829 & 100 & - & - & - & - & $f_{s}$ \\
\hline Erythrinidae & Hoplias malabaricus (Bloch, 1796) & - & - & - & - & 100 & $f_{S}$ \\
\hline \multicolumn{8}{|l|}{ Siluriformes } \\
\hline Callichthyidae & Corydoras paleatus (Jennyns, 1842) & 2.4 & 18.7 & 30.3 & 18.9 & 29.7 & $f m$ \\
\hline Loricariidae & Loricariichthys anus (Valenciennes, 1836) & - & - & 30 & 60 & 10 & $f_{S}$ \\
\hline \multirow[t]{2}{*}{ Heptapteridae } & Pimelodella laticeps (Eigenmann, 1917) & - & 6.5 & 54.3 & 20.5 & 18.6 & $f m$ \\
\hline & Rhamdia quelen (Quoy \& Gaimard, 1824) & 1.7 & 38 & 36.1 & 13.5 & 10.7 & $f_{s}$ \\
\hline \multirow[t]{2}{*}{ Pimelodidae } & Parapimelodus valenciennis (Kröyer, 1874) & - & 10.2 & 89.8 & - & - & $f_{s}$ \\
\hline & Pimelodus albicans (Valenciennes, 1840) & - & 31 & 3.4 & 17.2 & 48.3 & $f m$ \\
\hline \multicolumn{8}{|l|}{ Gadiformes } \\
\hline Phycidae & Urophycis brasiliensis (Kaup, 1858) & 80.1 & 15.6 & 2.1 & 2.1 & - & $m m$ \\
\hline \multicolumn{8}{|l|}{ Mugiliformes } \\
\hline Mugilidae & Mugil platanus Günther, 1880 & 32.2 & 14.4 & 46.9 & 3.7 & 2.8 & $c$ \\
\hline \multicolumn{8}{|c|}{ Atheriniformes } \\
\hline \multirow[t]{2}{*}{ Atherinidae } & Odontesthes argentinensis (Valenciennes, 1835) & 38.9 & 4.6 & 49.7 & 5.3 & 1.4 & er \\
\hline & O. bonariensis (Valenciennes, 1835) & 1.2 & 2.3 & 22.6 & 34.2 & 39.7 & $f m$ \\
\hline \multicolumn{8}{|c|}{ Cyprinodontiformes } \\
\hline Anablepidae & Jenynsia multidentata (Jenyns, 1842) & 2 & $<$ & 45.9 & 46.2 & 4.9 & $f m$ \\
\hline Poeciliidae & Cnesterodon decemmaculatus (Jenyns, 1842) & - & - & 100 & - & - & $f_{s}$ \\
\hline \multicolumn{8}{|c|}{ Gasterosteiformes } \\
\hline Syngnathidae & Syngnathus folletti (Herald, 1942) & 7.9 & 76.8 & 11 & 3 & 1.2 & er \\
\hline
\end{tabular}


Continued Table 2.

\begin{tabular}{|c|c|c|c|c|c|c|c|}
\hline \multicolumn{8}{|l|}{ Scorpaeniformes } \\
\hline Triglidae & Prionotus punctatus (Bloch, 1793) & 72.7 & 27.3 & - & - & - & $m m$ \\
\hline \multicolumn{8}{|l|}{ Perciformes } \\
\hline Pomatomidae & Pomatomus saltatrix (Linnaeus, 1766) & - & - & 100 & - & - & $m s$ \\
\hline \multirow[t]{2}{*}{ Carangidae } & Parona signata (Jenyns, 1841) & 27.3 & 63.6 & 9.1 & - & - & $m m$ \\
\hline & Trachurus lathami (Nichols, 1920) & 100 & - & - & - & - & $m s$ \\
\hline \multirow[t]{6}{*}{ Sciaenidae } & Cynoscion guatucupa (Cuvier, 1830) & 33.3 & 41.7 & - & 8.3 & 16.7 & $\mathrm{~mm}$ \\
\hline & Macrodon ancylodon (Bloch \& Schneider, 1801) & 6.6 & 68.9 & 15.9 & 7.1 & 1.5 & er \\
\hline & Menticirrhus americanus (Linnaeus, 1758) & 88.5 & 3.1 & 3.1 & 5.4 & - & $\mathrm{mm}$ \\
\hline & Micropogonias furnieri (Desmarest, 1823) & 9.4 & 8.7 & 51.3 & 25.5 & 5.1 & er \\
\hline & Paralonchurus brasiliensis (Steindachner, 1875) & 38.6 & 56.8 & 4.4 & $<$ & - & er \\
\hline & Pogonias cromis (Linnaeus, 1766) & 31 & 2.5 & 49 & 13.8 & 3.7 & $e r$ \\
\hline Cichlidae & Australoheros facetum (Jenyns, 1842) & - & - & 100 & - & - & $f_{s}$ \\
\hline \multirow[t]{2}{*}{ Percophidae } & Percophis brasiliensis Quoy \& Gaimard, 1825 & - & - & 100 & - & - & $m s$ \\
\hline & Stromateus brasiliensis (Fowler, 1906) & 66.7 & - & 33.3 & - & - & $m m$ \\
\hline \multicolumn{8}{|c|}{ Pleuronectiformes } \\
\hline \multirow[t]{2}{*}{ Paralichthyidae } & Paralichthys orbignyanus (Valenciennes, 1839) & 66.7 & 5.6 & 11.1 & 16.7 & - & er \\
\hline & P. patagonicus Jordan, 1889 & - & - & 100 & - & - & $m m$ \\
\hline Pleuronectidae & Oncopterus darwinii (Steindachner, 1874) & 100 & - & - & - & - & er \\
\hline \multirow[t]{3}{*}{ Cynoglossidae } & Symphurus plagusia (Bloch \& Schneider, 1801) & 54.2 & 15.3 & 6.9 & 23.6 & - & er \\
\hline & Total of species by site & 27 & 31 & 39 & 30 & 27 & \\
\hline & Average species captured by surveys & 9.8 & 10.9 & 12.8 & 10.1 & 9.3 & \\
\hline
\end{tabular}

M. americanus, and Prionotus punctatus, among others) mainly associated with the external area identified in the RA. These were discriminator species of the external area on several occasions (Table 4). Although this group of species occurred at similar salinities, they exhibit a strong discontinuity along axis 2 , allowing their separation into warm water species (C. guatucupa, Paralichthys orbygnianus, Anchoa marinii), and those associated with cold water ( $P$. punctatus, Symphurus plagusia, $U$. brasiliensis, among others).

The second group, associated with intermediate salinities (Fig. 4), consisted of estuarine residents species (M. furnieri, M. ancylodon, P. cromis, P. brasiliensis, among others) which occurred in and dominated abundance throughout all the surveys though they were especially discriminant of the middle area. This group presented a very low discontinuity along axis 2 and was associated with intermediate salinities. The low salinity waters contained typically freshwater species (Fig. 4). These species were on many occasions identified as discriminant species for the inner area and even also of the middle area (Table 4). Within this group, the species had a discontinuity along the temperature values, showing species associated with high temperatures (C. carpio, Loricarichthys anus, Astyanax eigenmaniorum), and with intermediate or low temperatures (O.jenynsii, Pimelodella laticeps, C. voga, among others).

When the sampling sites for each survey were overlaid and analyzed (Fig. 5), they were found to reflect the spatial pattern of species composition on axis 1 and the seasonal pattern of species composition on axis 2 . The distance along axis 1 between sampling stations varied between surveys, making evident the great variation in the length of the environmental gradient between the various surveys (Fig. 5).

\section{DISCUSSION}

Estuaries are characterized by a relatively low ichthyofaunal diversity but high abundance of individual taxa, most of which exhibit wide tolerance limits to the fluctuating conditions found within these systems (WHITFIELD, 1999). The Ajó river (RA) showed the characteristics of an estuary, low number of species, 

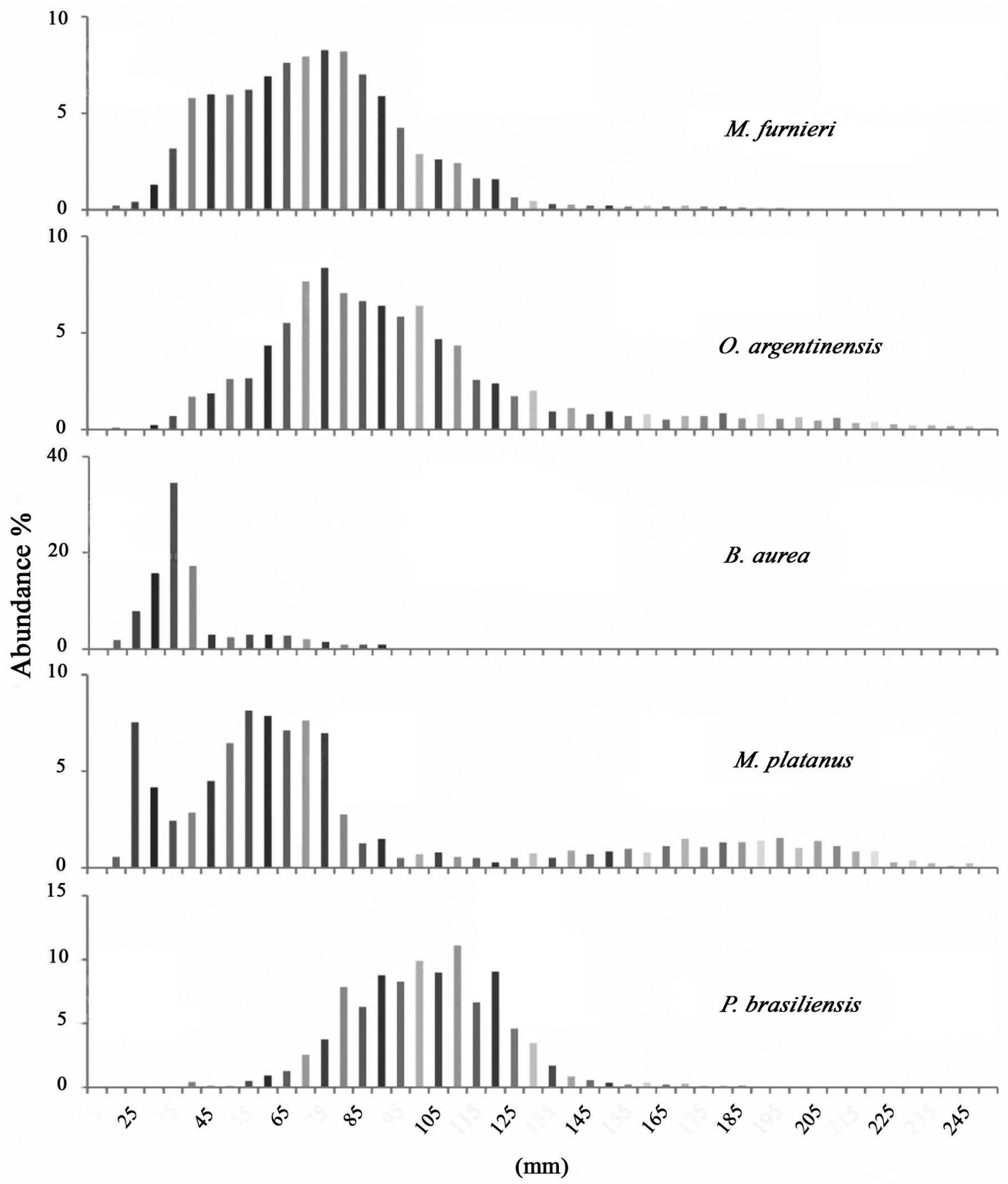

Figure 3. Relative length frequency distribution of the main species for the total surveys in the Ajó river. Vertical axis (y) has different scales according to species.

consistent with what has been found in the south-west Atlantic Ocean region in general (JAUREGUIZAR et al., 2003b, 2004, 2006; GARCIA; VIEIRA, 2002; GONZÁLEZ CASTRO et al., 2009a; GARCIA et al., 2010; ACUÑA PLAVAN et al., 2010; LORENZO et al., 2011), and only one species (M. furnieri) represented $\sim 90 \%$ of the total abundance. The top eight species that follow it in abundance attained $9.9 \%$ of the total catch, while the total contribution from the remaining 36 species was $0.9 \%$.

Different taxonomic groups can use estuaries, whether on a regular or permanent basis, taking advantage of the robust nature of the food webs within these systems (ACUÑA PLAVAN et al., 2010). In terms of estuarine use, different patterns are observed in many estuaries 
Table 3. Fish assemblages' areas identified spatially based on similarity between sampling sites along each survey. w: winter; sp: spring; su: summer; o: autumn.

\begin{tabular}{|c|c|c|c|c|c|c|}
\hline \multirow[t]{2}{*}{ Surveys } & \multirow[t]{2}{*}{ Date } & \multicolumn{5}{|c|}{ Sites by association areas } \\
\hline & & External & $\mathrm{M} / \mathrm{E}$ & Middle & $\mathrm{M} / \mathrm{I}$ & Internal \\
\hline w 07 & 09-13/09/2007 & 1 & & 23 & & 45 \\
\hline sp 07 & $06-10 / 11 / 2007$ & & & 12345 & & \\
\hline su 08 & $21-25 / 01 / 2008$ & 12 & & 3 & 4 & 5 \\
\hline о 08a & $07-11 / 04 / 2008$ & 123 & & & & 45 \\
\hline o $08 b$ & $04-08 / 05 / 2008$ & 12 & & 34 & & 5 \\
\hline w $08 \mathrm{a}$ & 03-07/07/2008 & 13 & & 24 & & 5 \\
\hline w $08 b$ & $01-05 / 09 / 2008$ & 12 & & 34 & & 5 \\
\hline sp 08 & $24-26 / 10 / 2008$ & 1 & & 24 & 3 & 5 \\
\hline su $09 \mathrm{a}$ & 03-07/01/2009 & 12 & & & & 345 \\
\hline su $09 b$ & $09-12 / 03 / 2009$ & 1 & & 23 & & 45 \\
\hline o 09 & $10-14 / 06 / 2009$ & 2 & & 3 & & 45 \\
\hline w 09 & $18-22 / 08 / 2009$ & 1 & 2 & 3 & 4 & 5 \\
\hline sp 09 & $19-23 / 10 / 2009$ & 13 & & 25 & & 4 \\
\hline
\end{tabular}

Table 4. Discriminant species recorded for each fish assemblage area over the study period. n: number of occurrences as discriminant species; EUFG: estuarine use by functional group; er: estuarine residents; $f s$ : freshwater stragglers; $f m$ : freshwater migrants; $m s$ : marine stragglers; $m m$ : marine migrants; $c$ : catadromus; $a$ : anadromus.

\begin{tabular}{|c|c|c|c|c|c|c|c|c|}
\hline \multicolumn{9}{|c|}{ Discriminant species } \\
\hline External & $\mathrm{n}$ & EUFG & Middle & $\mathrm{n}$ & EUFG & Internal & $\mathrm{n}$ & EUFG \\
\hline M. americanus & 9 & $m m$ & B. aurea & 6 & er & P. platana & 6 & er \\
\hline M. platanus & 8 & $c$ & P. cromis & 5 & er & C. voga & 5 & $f_{S}$ \\
\hline M. furnieri & 6 & er & O. argentinensis & 5 & er & O. jenynsii & 5 & $f s$ \\
\hline O. argentinensis & 6 & er & M. ancylodon & 5 & $e r$ & C. paleatus & 3 & $f m$ \\
\hline P. brasiliensis & 6 & er & C. paleatus & 4 & $f m$ & R. quelen & 4 & $f_{s}$ \\
\hline B. aurea & 5 & er & P. laticeps & 3 & $f m$ & C. interruptus & 2 & $f_{s}$ \\
\hline M. ancylodon & 5 & er & P. platana & 3 & er & M. furnieri & 2 & er \\
\hline U. brasiliensis & 5 & $m m$ & M. furnieri & 4 & er & C. carpio & 2 & $f m$ \\
\hline P. cromis & 4 & $e r$ & J. multidentata & 4 & $f m$ & B. aurea & 2 & er \\
\hline O. darwinii & 3 & er & M. platanus & 4 & $c$ & P. albicans & 3 & $f m$ \\
\hline S. folletti & 3 & er & R. quelen & 3 & $f_{s}$ & P. cromis & 2 & $e r$ \\
\hline P. albicans & 2 & $f m$ & P. brasiliensis & 2 & er & P. laticeps & 2 & $f m$ \\
\hline P. orbignyanus & 1 & $m m$ & A. marinii & 2 & er & A. eigenmanniorum & 1 & $f_{S}$ \\
\hline P. punctatus & 1 & $m m$ & C. $\operatorname{vog} a$ & 2 & $f_{s}$ & L. anus & 1 & $f_{s}$ \\
\hline P. signata & 1 & $\mathrm{~mm}$ & C. interruptus & 2 & $f_{s}$ & J. multidentata & 1 & $f m$ \\
\hline \multirow[t]{3}{*}{ S. plagusia } & 1 & er & C. carpio & 2 & $f m$ & O. argentinensis & 1 & er \\
\hline & & & O. jenynsii & 2 & $f_{s}$ & S. plagusia & 1 & er \\
\hline & & & & & & L. grossidens & 1 & $a$ \\
\hline
\end{tabular}

in the world, the most characteristic pattern being the overwhelming dominance of marine migrant species in terms of biomass and also in species composition (ELLIOT et al., 2007; FRANCO et al., 2008). However, the small estuarine residents species generally form a less dominant group in terms of biomass but are often numerically very abundant (WHITFIELD; HARRISON, 2003). Studies in the RdlP estuary in terms of presence/absence (JAUREGUIZAR et al., 2003a), biomass (JAUREGUIZAR et al., 2004, 2006; LORENZO et al., 2011) or abundance 
Table 5. Summary of canonical correspondence analysis (CCA), for the study period in the Ajó river; and the respective values of significance $(p<0.05)$. S: salinity, $\mathrm{T}^{\circ}$ : temperature, $\mathrm{pp} 30$ : rainfall 30 days prior to the date of sampling, RdlP: discharge of the Río de la Plata, MS: Suspension material, pp15: precipitation 15 days prior to the date of sampling, O: Oxygen.

\begin{tabular}{|c|c|c|c|}
\hline \multirow{2}{*}{\multicolumn{2}{|c|}{ Correlation matrix }} & \multicolumn{2}{|c|}{ Axes } \\
\hline & & 1 & 2 \\
\hline \multicolumn{2}{|l|}{ Eigenvalues } & 0.148 & 0.091 \\
\hline \multicolumn{2}{|c|}{ Species-Environment correlations } & 0.775 & 0.749 \\
\hline \multicolumn{2}{|c|}{ Cumulative $\%$ variance of $\mathrm{sp}$. data } & 8.9 & 14.4 \\
\hline \multicolumn{2}{|c|}{$\begin{array}{l}\text { Cumulative \% variance of sp.-environmental } \\
\text { relation }\end{array}$} & 46.6 & 75.4 \\
\hline \multicolumn{2}{|c|}{ Sum of all unconstrained eigenvalues } & \multicolumn{2}{|c|}{1.654} \\
\hline Abiotic variables & Significance $p<0.05$ & & \\
\hline S & 0.002 & -0.757 & 0.079 \\
\hline $\mathrm{T}^{\circ}$ & 0.002 & -0.081 & 0.681 \\
\hline pp30 & 0.024 & 0.081 & -0.33 \\
\hline RdlP & 0.01 & 0.003 & 0.285 \\
\hline MS & 0.27 & & \\
\hline pp15 & 0.39 & & \\
\hline $\mathrm{O}$ & 0.63 & & \\
\hline $\mathrm{pH}$ & 0.67 & & \\
\hline
\end{tabular}

(GARCIA et al., 2010) determined that the estuarine and marine migrant species were better represented. The pattern observed in the RA (this study) does not correspond to this last environment, but resembles the pattern found in a similar area associated with the RdlP estuary along the Uruguayan coast, the Pando river. Functional groups in the Pando river were mainly composed of freshwater straggler and estuarine species in terms of diversity and few estuarine species dominated the environment in terms of abundance and biomass (ACUÑA PLAVAN et al., 2010). The reason for the dominance of freshwater stragglers species may lie in the particular conditions of the region. Since from a geomorphological point of view, the RA forms part of the coastal plain, located in the Región Deprimida del Salado (VIOLANTE et al., 2001), where several water courses have low slope and endorheic or arheic drainage (QUIRÓS et al., 2002). This environment suffers extensive and prolonged periodic flooding (QUIRÓS et al., 2002), and when it occurs, it allows the south limit of some ParanoPlatense species to move to southward latitudes and reaches the latitude of RA (LÓPEZ et al., 2008). Consequently, new habitats are available in the RA, which allows the occurrence of some freshwater species in the upper reach. Another phenomenon that is directly related to the occurrence of freshwater species in the area is the increase in flow of the main rivers that form the RdlP system, especially the Paraná River (JAUREGUIZAR et al., 2003, 2004). This causes a southward inflow of fresh water into Samborombón bay, and allows the intrusion into RA of some species that were mentioned as rare and that mainly inhabit the RdlP basin (p. obs. Salminus maxillosus, Luciopimelodus pati, Prochilodus lineatus and Pseudoplatystoma corruscans), among these species we recorded Raphiodon vulpinus. Contrary to the situation described above, the times of drought and low runoff of the RdlP allowed the arrival and stay of marine migrants and marine stragglers species. However, the majority of these species enter the estuary as a result of trophic opportunism, some current or wind, or flooding, leading to estuarine residents species' being the most widely distributed and abundant in the system. Even if the contribution of the most abundant species ( $>1 \%$ ) is ignored; more than $50 \%$ of the total abundance is still represented by estuarine residents species, consistent with the findings in a similar environment associated with the RdlP (ACUÑA PLAVÁN et al., 2010), and in the RdlP itself (JAUREGUIZAR et al., 2004).

The RAfish assemblages were mainly determined by the salinity gradient that restricted the presence of freshwater and marine species along the river. Several authors have done similar research on hundreds of estuarine systems around the world and agree that salinity is a determining factor in the spatial community structure, which is related to the salt tolerance of the species (GUNTER, 1956; LONERAGAN et al., 1987; PETERSON; ROSS, 1991; WHITFIELD, 1999; ABLE et al., 2001; MARTINO; ABLE, 2003; JAUREGUIZAR et al., 2004; HARRISON; WHITFIELD 2006; ELLIOTT et al., 2007). The RA estuary has low or intermediate salinities, and the main gradient is determined by the freshwater input in the upper region and of mixohaline or euryhaline waters across Samborombón bay. According to the classification proposed by the Venice System for salinity regimes, the estuarine regions in the RA were between oligohaline (2.1) and polyhaline (22.9). This explains the fact that estuarine residents species (e.g. M. furnieri, O. argentinensis, $P$. brasiliensis, $B$. aurea and $P$. cromis), which are adapted to changes in salinity, were dominant in this environment, regardless of the spatial structure recorded in the system. The diversity of freshwater and estuarine species together with the abundance of the dominant species play a major role in determining the composition and dynamics of fish from the areas identified. 


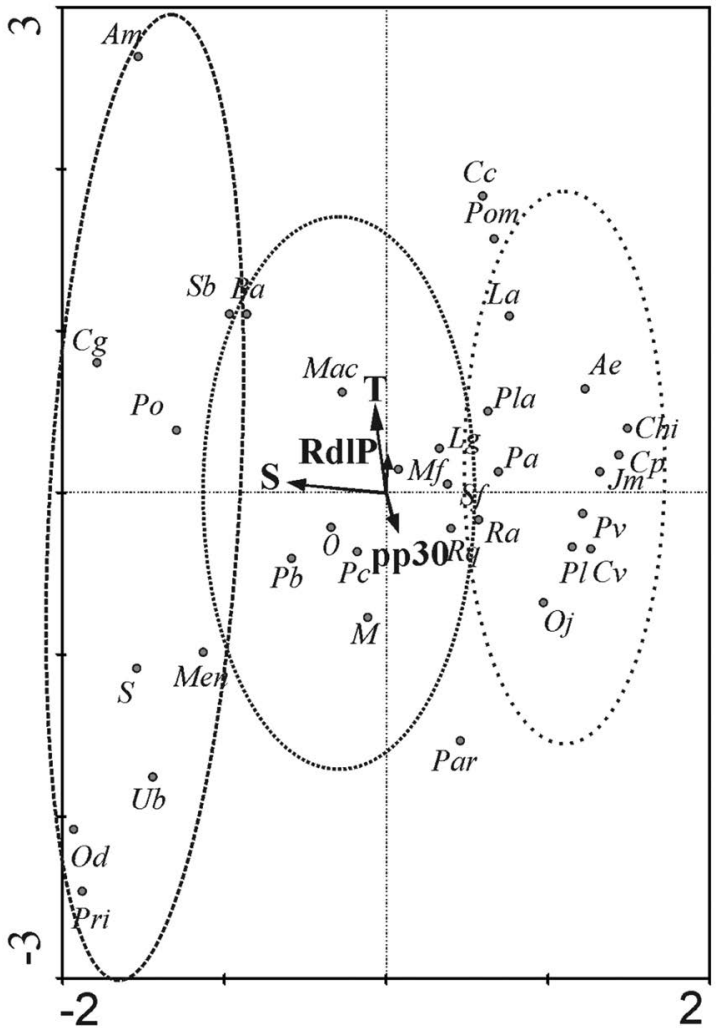

Figure 4. Canonical Correspondence Analysis ordination diagram obtained from the collected species (individuals/hour of fishing), corresponding to the entire sampling period (winter 2007 - spring 2009), and its relationship to environmental variables in the Ajó river. Am: A. marinii; Ae: A. eigenmanniorum; Ba: B. aurea; Chi: C. interruptus; Cp: C. paleatus; $\mathrm{Cg}:$ C. guatucupa; $\mathrm{Cv}$ : C. voga; Cc: C. carpio; Jm: J. multidentata; La: L. anus; Lg: L. grossidens; Mac: M. ancylodon; Men: M. americanus; Mf: M. furnieri; M: M. platanus; $\mathrm{O}$ $O$. argentinensis; $\mathrm{Oj}: O$. jenynsii; Od: $O$. darwinii; Po: P. orbignyanus; $\mathrm{Pb}:$ P. brasiliensis; $\mathrm{Pv}$ : $P$. valenciennis; Par: $P$. signata; $\mathrm{Pl}$ : $P$. laticeps; Pa: $P$. albicans; Pla: $P$. platana; Pc: $P$. cromis; Pom: $P$. saltatrix; Pri: P. punctatus; Ra: R. arcuata; Rq: R. quelen; Sb: S. brasiliensis; S: S. plagusia; Sf: S. folletti; Ub: U. brasiliensis; T: Temperature; S: salinity; RdlP: Discharge of RdlP; pp30: cumulative rainfall of 30 days before each sampling date.

During periods of low salinity numerous freshwater species were recorded. These species have occasionally been cited for mixohaline surrounding environments, and their relative resistance to salinity is well known $(P$. laticeps (GARCIA; ALMIRÓN, 1990; GARCIA et al., 2003; SOLARI et al., 2009), C. carpio (SOLARI et al., 2009; ACUÑA PLAVAN et al., 2010), O. bonariensis (SOLARI et al., 2009) Parapimelodus valenciennesi, Pimelodus albicans (SOLARI et al., 2009; ACUÑA PLAVAN et al., 2010; GARCIA et al., 2010), and Jenynsia multidentata (GARCIA et al., 2004; SOLARI et al., 2009)). Furthermore, a great diversity of freshwater stragglers

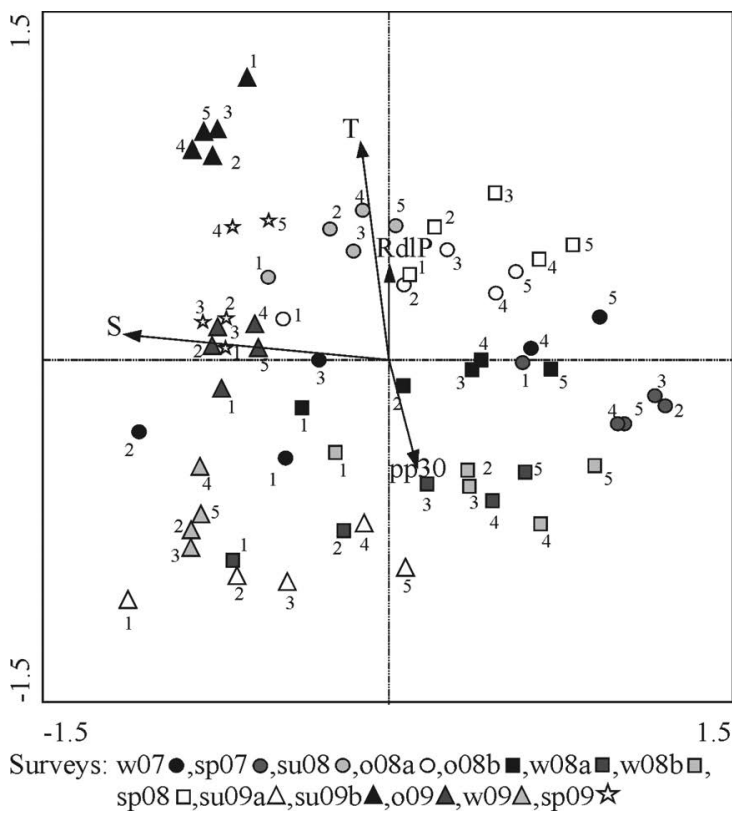

Figure 5. Canonical Correspondence Analysis ordination diagram obtained from the sampling sites corresponding to the entire sampling period, and its relation to environmental variables in the Ajó river. w: winter; sp: spring; su: summer; o: autumn; 1, 2, 3, 4 y 5 Sampling sites; T: temperature; S: salinity; RdlP: discharge of Río de la Plata; pp30: cumulative rainfall of 30 days before each sampling date.

species were collected within the RA, some of them being occasional (e.g. Cnesterodon decemmaculatus, Hoplias malabaricus, Hyphessobrycon anisistii, H. togoi, L. anus and $R$. vulpinus), and others having a more consistent occurrence and abundance pattern (e.g. C. interruptus, $C$. voga, $O$. jenynsii and $R$. quelen), taking advantage of the wide availability of habitats and abundant food, which is characteristic of estuarine environments. This explains why, during periods of low salinities, freshwater species are diagnostic for the inner area and even for the middle area (Table 4), where they co-occur with marine migrants species (e.g. M. americanus and $U$. brasiliesnsis). However, freshwater species do not reach the outer area, which was only inhabited by marine species (marine migrants and marine stragglers), regardless of the extent of the salt gradient of the system. Estuarine resident species were present throughout the estuarine system, presenting some segregation depending on the preferred salt gradient. In this regard, JAUREGUIZAR et al. (2004) found that estuarine species of the family Sciaenidae showed different trends in abundance within the estuarine salinity gradient of the RdlP, where the higher abundances of M. furnieri occurred in lower salinity than M. ancylodon. This same pattern was observed in this study; the presence of $M$. 
furnieri is always associated with the adjoining innermost area where $M$. ancylodon and $P$. brasiliensis occur. However, when the average salinity of the system begins to rise, the fish assemblage composition and extension of the different areas change. A consistent decrease in the freshwater component and, simultaneously, an increase of estuarine residents, together with an intrusion toward the upper reach of the system by marine migrants and marine stragglers, were observed.

As has been observed in other estuaries (LONERAGAN et al., 1987; POTTER; HYNDES, 1999; THIEL; POTTER, 2001), the amplitude of the environment gradient, mainly determined by the adjacent water condition, was what determined the consistent presence of fish assemblage areas along the RA. The most pronounced variation in fish assemblage composition occurred during seasons in which the RdlP discharge and rainfall had average values and the RA showed the higher and longest environmental gradient. Moreover, periods dominated by a fresher water (due to a higher input of rainwater and/or irregular advection of freshwater from the RdlP), or saltier waters (due to a decrease in RdlP discharge and low rain frequency) give a lesser gradient along the RA study area resulting in a more homogeneous estuary in terms of species composition, with the presence of estuarine residents species together with freshwater or marine species, respectively.

This study showed that the variations in salinity play an important role in the diversity of available habitats and in the use of estuaries by juvenile fish. In addition, rainfall across the region and RdlP discharge, along with the seasonal dynamics of the RdlP estuarine zone, determined the salinity range and gradient extension within the system. The current global warming trend is predicted to alter significantly the water balance of the RdlP drainage area, leading to an increase in rainfall and river runoff over this region (HIRABAYASHI et al., 2008; KNAPP et al., 2008), and will significantly increase the frequency of large-scale floods (MILLY et al., 2002; HIRABAYASHI et al., 2008). In addition, an increase in the temperature of the sea surface; and of the speed of the winds from the south is other climatic factors affecting the survey area (ORTEGA et al., 2013). This will produce permanent changes in the community composition that will bring future variations in the structure and predatorprey relationships of the fish community (STENSETH et al., 2002), compromising the coastal stocks and the diverse fisheries of adjacent waters, with important socio-economic impacts (JAUREGUIZAR et al., 2004).
Most of the individual species were represented only by juveniles, which demonstrate the important role of RA as a nursery area. As has been reported by many authors in studies on similar estuarine systems (POTTER et al., 1990; PATERSON; WHITFIELD, 2000; ELLIOTT; HEMINGWAY, 2002), this indicates that this shallow habitat is very important for many fish species providing them with nursery, shelter and protection areas from large piscivorous fishes, marine mammals and seabirds, shielding them from predation during at least the early growth stages. This study suggested the important role of small estuarine systems as shelter and potential nursery areas for numerous fish species, including several commercially important species. Further, the study highlights the importance of including abiotic factors as significant variables in management plans. It is vital to encourage longer term studies to better understand the cumulative effects of climate change on estuarine environments and adjacent areas.

\section{ACKNOWLEDGEMENTS}

The authors wish to express their thanks to L. Massolo, F. Cortes, J. Waessle, T. Maiztegui, G. Cadaveira, D. Barrasso, F. Gorini, C. Lasta, V. Mugnaschi y M. Cuello for their friendship, cooperation and commitment during the course of the study. This study was carried out within the scope of the project SeCyT PICT Nro. 31982/05 to AJJ, INIDEP, CIC and CONICET. We also thank the Centro de Estudios de Recursos Costeros (CERC) of the Partido de la Costa for accommodation and for providing a place to process our samples. We also thank L. O. Lucifora for the English revision, Chief Editor for Portugese translation of the abstract, and Dr. Malbeco for his inspiration. This is INIDEP contribution no 1935 .

\section{REFERENCES}

ABLE, K. W.; NEMERSON, D. M.; BUSH, R. O.; LIGHT, P. Spatial variation in Delaware Bay (USA) marsh creek fish assemblages. Estuaries, v. 24, n. 3, p. 441-452, 2001.

ACUÑA PLAVAN, A.; PASSADORE, C.; GIMENEZ, L. Fish assemblage in a temperate estuary on the uruguayan coast: seasonal variation and environmental influence. Braz. J. Oceanogr., v. 58, n.4, p. 299-314, 2010.

AUAD, G.; MARTOS, P. Climate Variability of the Northern Argentinean Shelf Circulation: impact on Engraulis Anchoita. Int. J. Ocean. Clim. Syst., v. 3, n. 1, p. 17-43, 2012.

AZPELICUETA, M. M.; ALMIRÓN, A. Cyphocharax spilotus (Characiformes, Curimatidae) en el río Paraná y afluentes del Río de la Plata. Neotropica, v. 37, n. 98, p. 158-159, 1991. 
BECK, M. W., HECK, K. L. JR.; ABLE, K. W.; CHILDERS, D. L.; EGGLESTON, D. B.; GILLANDERS, B. M.; HALPERN, B.; HAYS, C. G.; HOSHINO, K.; MINELLO, T. J.; ORTH, R. J.; SHERIDAN, P. F.; WEINSTEIN, M. P. The identification, conservation, and management of estuarine and marine nurseries for fish and invertebrates. BioScience, v. 51, n. 8, 633-641, 2001.

BLABER, S. J. M. Tropical estuarine fishes: ecology, exploration and conservation. Oxford: Wiley-Blackwell Science, 2008. $384 \mathrm{p}$.

BLABER, S. J. M.; BREWER, D. T.; SALINI, J. P. Species composition and biomasses of fishes in different habitats of a tropical Northern Australian Estuary: Their occurrence in the adjoining sea and estuarine dependence. Estuar. Coast. Shelf Sci., v. 29, n. 6, p. 509-531, 1989.

BLONDEL, J. Guilds or functional groups: does it matter? Oikos, v. 100, n. 2, p. 223-231, 2003.

CAROL, E.; KRUSE, E.; POUSA, J. Environmental hydrogeology of the southern sector of the Samborombon Bay wetland, Argentina. Environ. Geol., v. 54, n. 1, p. 95102, 2007.

CASCIOTTA, J. R.; ALMIRÓN, A. E.; AZPELICUETA, M. M. Astyanax pampa (Characiformes, Characidae), a new species from the southernmost boundary of the Brazilian subregion, Argentina. Rev. Suisse Zoo., v. 112, n. 2, p. 401-408, 2005.

CLARKE, K. R.; WARWICK, R. M. Changes in marine communities: an approach to statistical analysis and interpretation. 2. ed. Plymouth: Plymouth Marine Laboratory: Primer-e, UK, 2001.

COCONIER, E. Bahía de Samborombón y Punta Rasa. In: DI GIACOMO, A. S.; DE FRANCESCO, M. V.; COCONIER, E. G. (Eds.). Áreas importantes para la conservación de las aves en Argentina. Sitios prioritarios para la conservación de la biodiversidad. Buenos Aires: Aves Argentinas/Asociación Ornitológica del Plata, 2007. p. 46-47.

CODIGNOTTO, J. O.; DRAGANI, W. C.; MARTIN, P. B.; SIMIONATO, C. G.; MEDINA, R. A.; ALONSO, G. Windwave climate change and increasing erosion in the outer Río de la Plata, Argentina. Cont. Shelf Res., v. 38, p. 110-116, 2012.

COLAUTTI, D. C. Sobre la utilización de trampas para peces en las lagunas pampásicas. Rev. Ictiol., v. 6, n. 1/2, p. 17-23, 1998.

ELLIOTT, M.; HEMINGWAY, K. L. Fishes in Estuaries. Oxford: Blackwell Science, 2002.

ELLIOTT, M.; WHITFIELD, A. K.; POTTER, I. C.; BLABER, S. J. M.; CYRUS, D. P.; NORDLIE, F. G.; HARRISON, T. D. The guild approach to categorizing estuarine fish assemblages: a global review. Fish Fish., v. 8, n. 3, p. 241$268,2007$.

FRANCO, A.; FRANZOI, P.; TORRICELLI, P. Structure and functioning of Mediterranean Lagoon fish assemblages: a key for the identification of water body types. Estuar. Coast. Shelf Sci., v. 79, n. 3, p. 549-558, 2008.

GARCIA, A. M.; VIEIRA, J. The link between El Niño, freshwater outflow and the dynamics of an estuarine fish assemblage in South Brazil. Estuar. Coast. Sci. Assoc. Bull., v. 41, p. 36-37, 2002.

GARCIA, M. L.; ALMIRÓN, A. Presencia de Pimelodella laticeps (Pisces, Pimelodidae) en un ambiente de salinidad variable. Neotrópica, v. 37, p. 66, 1990.
GARCIA, A. M.; RASEIRA, M. B.; VIEIRA, J. P.; WINEMILLER, K. O.; GRIMM, A. M. Spatiotemporal variation in shallow-water freshwater fish distribution and abundance in a large subtropical coastal lagoon. Environ. Biol. Fish., v. 68, n. 3, p. 215-228, 2003.

GARCIA, A. M.; VIEIRA, J. P.; WINEMILLER, K. O.; RASEIRA, M. B. Reproductive cycle and spatiotemporal variation in abundance of the one-sided livebearer Jenynsia multidentata, in Patos Lagoon, Brazil. Hydrobiologia, v. 515, n. 1/3, p. 39-48, 2004.

GARCIA, M. L.; CUELLO, M.; SOLARI, A.; MILESSI, A. C. Is Oreochromis niloticus invading the Samborombón Bay, Río de la Plata, Argentina? Rev. Mus. Arg. Cien. Nat., v. 12, n. 2, p. 117-120, 2010.

GONZÁlEZ CASTRO, M.; DÍAZ DE ASTARLOA, J. M.; COUSSEAU, M. B.; FIGUEROA, D. E.; DELPIANI, S. M.; BRUNO, D. O.; GUZZONI, J. M.; BLASINA, G. E.; DELI ANTONI, M. Y. Fish composition in a South-Western Atlantic temperate coastal lagoon: spatial-temporal variation and relationships with environmental variables. J. Mar. Biol. Assoc. UK., p. 1-12, 2009a.

GUERRERO, R. A.; ACHA, E. M.; FRAMIÑAN, M. B.; LASTA, C. A. Physical oceanography of the Río de la Plata estuary, Argentina. Continent. Shelf Res., v. 17, n. 7, p. 727$742,1997$.

GUNTER, G. Some relations of faunal distributions to salinity in estuarine waters. Ecology, v. 37, p. 616-619, 1956.

HARRISON, T. D.; WHITFIELD, A. K. Temperature and salinity as primary determinants influencing the biogeography of fishes in South African estuaries. Estuar. Coast. Shelf Sci., v. 66, n. 1/2, p. 335-345, 2006.

HIRABAYASHI, Y.; KANAE, S.; EMORI, S.; OKI, T.; KIMOTO, M. Global projections of changing risks of floods and droughts in a changing climate. Hydrol. Sci. J., v. 53, p. 754-772, 2008.

JAUREGUIZAR, A. J.; MENNI, R. C.; BREMEC, C. S.; MIANZAN, H. W.; LASTA, C. A. Fish assemblage and environmental patterns in the Río de la Plata estuary. Estuar. Coast. Shelf Sci., v. 56, n. 5/6, p. 921-933, 2003 a.

JAUREGUIZAR, A. J.; BAVA, J.; CAROZZA, C. R.; LASTA, C. A. Distribution of whitemouth croaker Micropogonias furnieri in relation to environmental factors at the Río de la Plata estuary, South America. Mar. Ecol-Prog. Ser., v. 255, p. 271-282, 2003b.

JAUREGUIZAR, A. J.; MENNI, R.; GUERREIRO, R.; LASTA, C. Environmental factors structuring fish communities of the Rio de la Plata estuary. Fish. Res., v. 66, n. 2/3, p. 195-211, 2004.

JAUREGUIZAR, A. J.; MILESSI, A. C. Assessing the sources of the fishing down marine food web process in the ArgentineanUruguayan Common Fishing Zone. Sci. Mar., v. 72, n. 1, p. 25-36, 2008.

JONGMAN, R.; TER BRAAK, C.; VAN TONGEREN, O. Data Analysis in Community and Landscape Ecology. Cambridge: Cambridge University press, 1995. $299 \mathrm{p}$.

KNAPP, A. K.; BEIER, C.; BRISKE, D. D.; CLASSEN, A. T.; LUO, Y.; REICHSTEIN, M.; SMITH, M. D.; SMITH, S. D.; BELL, J. E.; FAY, P. A.; HEISLER, J. L.; LEAVITT, S. W.; SHERRY, R.; SMITH, B.; WENG, E. Consequences of More Extreme Precipitation Regimes for Terrestrial Ecosystems. BioScience, v. 58, n. 9, p. 811-821, 2008. 
LOBRY, J.; MOURAND, L.; ROCHARD, E.; ELIE, P. Structure of the Gironde estuarine fish assemblages: a comparison of European estuaries perspective. Aquat. Living Resour., v. 16, n. 2 , p. $47-58,2003$.

LONERAGAN, N. R.; POTTER, I. C.; LENANTON, R. C. J.; CAPUTI, N. Influence of environmental variables on the fish fauna of the deeper waters of a large Australian estuary. Mar. Biol., v. 94, n. 4, p. 631-641, 1987.

LÓPEZ, H. L.; MENNI, R. C.; DONATO, M.; MIQUELARENA, A. M. Biogeographical revision of Argentina (Andean and Neotropical Regions): an analysis using freshwater fishes. J. Biogeogr., v. 35, p. 1564-1579, 2008.

LORENZO, M. I.; DÍAZ DE ASTARLOA, J. M.; NORBIS, W.; COUSSEAU, M. B. Long term fish assemblages as units of management in a temperate estuary (Río de la Plata - SW Atlantic Ocean). Braz. J. Oceanogr., v. 59, n.1, p. 43-59, 2011.

MARTIN, J. P.; BASTIDA, R. Population structure, growth and production of Laeonereis culveri (Nereididae: Polychaeta) in tidal flats of Río de la Plata estuary, Argentina. J. Mar. Biol. Assoc. U. K. V. 86, n. 2, p. 235-244, 2006.

MARTINO, E. J.; ABLE, K. W. Fish assemblages across the marine to low salinity transition zone of a temperate estuary. Estuar. Coast. Shelf Sci., v. 56, p. 969-987, 2003.

MATHIESON, S.; CATTRIJSSE, A.; COSTA, M. J.; DRAKE, P.; ELLIOTT, M.; GARDNER, J.; MARCHAND, J. Fish assemblages of European tidal marshes: a comparison based on species, families and functional guilds. Mar. Ecol.: Prog. Ser., v. 204, p. 225-242, 2000.

MENNI, R. C.; RINGUELET, R. A.; ARÁMBURU, R. H. Peces marinos de la Argentina y Uruguay. Buenos Aires: Hemisferio Sur. 1984. 359 p.

MILLY, P. C. D.; WETHERALD, R. T.; DUNNE, K. A.; DELWORTH, T. L. Increasing risk of great floods in a changing climate. Nature, v. 415, p. 514-517, 2002.

MIQUELARENA, A. M.; MENNI, R. C. Astyanax tumbayaensis, a new species from northwestern Argentina highlands (Characiformes: Characidae) with a key to the Argentinean species of the genus and comments on their distribution. Rev. Suisse Zoo., v. 112, p. 661-676, 2005.

MIQUELARENA, A. M.; LÓPEZ, H. L. Hyphessobrycon togoi, a new species from the La Plata basin (Teleostei: Characidae) and comments about the distribution of the genus in Argentina. Rev. Suisse Zoo., v. 113, n. 4, p. 817-828, 2006.

ORTEGA, L.; CASTILLA, J.; ESPINO, M.; YAMASHIRO, C.; DEFEO, O. Effects of fishing, market price, and climate on two South American clam species. Mar. Ecol. Prog. Ser., v. 469 , p. 71-85, 2012

ORTEGA, L.; CELENTANO, E.; FINKL, C.; DEFEO, O. Effects of Climate Variability on the Morphodynamics of Uruguayan Sandy Beaches. J. Coast. Res., v. 29, n. 4, p. 747-755, 2013.

PASQUINI, A. I.; DEPETRIS, P. J. Discharge trends and flow dynamics of South American rivers draining the southern Atlantic seaboard: an overview. J. Hydrol., v. 333, p. 385-399, 2007.
PATERSON, A. W.; WHITFIELD, A. K. Do shallow-water habitats function as refuges for juvenile fishes? Estuar. Coast. Shelf Sci., v. 51, p. 359-364, 2000.

PETERSON, M. S.; ROSS, S. T. Dynamics of littoral fishes and decapods along a coastal river-estuarine gradient. Estuar. Coast. Shelf Sci., v. 33, n. 5, p. 467-483, 1991.

POTTER, I. C.; BECKLEY, L. E.; WHITFIELD, A. K.; LENANTON, R. C. J. Comparisons between the roles played by estuaries in the life cycles of fishes in temperate Western Australia and Southern Africa. Environ. Biol. Fish., v. 28, p. 143-178, 1990.

POTTER, I. C.; HYNDES, G. A. Characteristics of the ichtyofaunas of southwestern Australian estuaries, including comparisons with holartic estuaries elsewhere in temperate Australia: A review. Aust. J. Ecol., v. 24, p. 395-421, 1999.

QUIRÓS, R.; ROSSO, J.; RENNELLA, A.; SOSNOVSKY, A.; BOVERI, M. Análisis del estado trófico de las lagunas pampeanas (Argentina). Interciencia, v. 27, n. 11, p. 584-591, 2002.

RINGUELET, R. A.; ARÁMBURU, R. H.; DE ARÁMBURU, A. A. Los peces argentinos de agua dulce. Buenos Aires: Comisión Científica de la Provincia de Buenos Aires. 1967, p. 602 .

SIMIONATO, C. G.; DRAGANI, W. C.; NUÑEZ, M. N.; ENGEL, M. A set of 3-D nested models for tidal propagation from the Argentinean Continental Shelf to the Río de la Plata Estuary: I. M2. J. Coastal Res., v. 20, p. 893-912, 2004.

SIMIONATO, C. G.; VERA, C. S.; SIEGISMUND, F. Surface wind variability on seasonal and interannual scales over Río de la Plata area. J. Coastal Res., v. 21, p. 770-783, 2005.

SOLARI, A.; GARCIA, M. L.; JAUREGUIZAR, A. J. Fish fauna from the Ajó river in Campos del Tuyú National Park, province of Buenos Aires, Argentina. Check List, v. 5, p. 807$811,2009$.

STENSETH, N. C.; MYSTERUD, A.; OTTERSEN, G.; HURRELL, J. W.; CHAN, K.; LIMA, M. Ecological effects of climate fluctuations. Science, v. 297, p. 1292-1296, 2002.

THIEL, R.; POTTER, I. C. The ichtyofaunal composition of the Elbe Estuary: an analysis in space and time. Mar. Biol., v. 138, p. 603-616, 2001.

THORNTHWAITE, C. W. An approach toward a rational classification of climate. Geogr. Rev., v. 38, p. 55-94, 1948.

VIOLANTE, R.A.; PARKER, G.; CAVALlOTTO, J. L. Evolución de las llanuras costeras del este bonaerense entre bahía Samborombón y la laguna Mar Chiquita durante el Holoceno. Rev. Asoc. Geol. Arg., v. 56, n. 1, p. 51-66, 2001.

WHITFIELD, A. K. 1999. Ichthyofaunal assemblages in estuaries: A South African case study. Rev. Fish Biol. Fisher., v. 9, n. 2, p. 151-186, 1999.

WHITFIELD, A. K.; HARRISON, T. D. River flow and fish abundance in a South African estuary. J. Fish Biol., v. 62, p. 1467-1472, 2003. 